\title{
Orange Tree Fibrous Root Length Distribution in Space and Time
}

\author{
Kelly T. Morgan ${ }^{1}$ \\ Soil and Water Science Department, University of Florida, Southwest Florida REC, 2686 SR 29 N, \\ Immokalee, FL 34142 \\ T.A. Obreza \\ Soil and Water Science Department, University of Florida, P.O. Box 110290, Gainesville, FL 32611 \\ J.M.S. Scholberg \\ Agronomy Department, University of Florida, P.O. Box 110500, Gainesville, FL 32611
}

\begin{abstract}
AdDitional INDEX words. citrus, Entisols
Abstract. Understanding the growth pattern of fibrous, orange tree [Citrus sinensis (L.) Osbeck] roots enables proper fertilizer placement to improve nutrient uptake efficiency and to reduce nutrient leaching below the root zone. The objective of this study was to develop relationships defining citrus fibrous root length density (FRLD) as a function of soil depth, distance from the tree trunk, and tree size. Root systems of 18 trees with tree canopy volumes (TCV) ranging from 2.4 to $34.3 \mathrm{~m}^{3}$ on two different rootstocks and growing in well-drained sandy soils were sampled in a systematic pattern extending $2 \mathrm{~m}$ away from the trunk and $0.9 \mathrm{~m}$ deep. Trees grown on Swingle citrumelo [Citrus paradisi Macf. $\times$ Poncirus trifoliata (L.) Raf.] rootstock had significantly greater FRLD in the top $0.15 \mathrm{~m}$ than trees on Carrizo citrange $(C$. sinensis $\times P$. trifoliata). Conversely, Carrizo citrange had greater FRLD from 0.15 to $0.75 \mathrm{~m}$ below the soil surface. FRLD was significantly greater for 'Hamlin' orange trees grown on Swingle citrumelo rootstock at distances less than $\mathbf{0 . 7 5} \mathrm{m}$ from the tree trunk compared with those on Carrizo citrange. Fibrous roots of young citrus trees developed a dense root mat above soil depths of $0.3 \mathrm{~m}$ that expanded both radially and with depth with time as trees grow and TCV increased. Functional relationships developed in this study accounted for changes in FRLD with increase in tree size.
\end{abstract}

Root system structure determines the volume of soil accessible to crop plants as well as the pathway for water and solute uptake (Kramer and Boyer, 1995). Increasing the length of small-diameter fibrous roots within a crop root system increases the amount of water and nutrients available to the crop (Tinker and Nye, 2000). The goal of fertilizer application is to place nutrients within the crop root zone to ensure the most efficient nutrient uptake. Maintaining sufficient water and nutrient concentrations within soil occupied by the crop root system is essential for optimal nutrient uptake (Scholberg et al., 2002). Therefore, understanding the spatial distribution of fibrous roots is essential to ensure proper fertilizer placement, improve nutrient uptake efficiency, and reduce leaching below the root zone.

Several Florida studies showed that tree size and yield were related to fibrous root dry weight density or distribution in the deep sandy soils of central Florida (Castle and Krezdorn, 1975; Ford, 1954, 1964, 1968, 1969, 1972). Castle and Krezdorn (1975) described two general types of citrus root systems, one characterized by extensive lateral and vertical development and the other by intensive higher fibrous root density near the soil surface. Trees on rough lemon (Citrus jambhiri Lush), Volkamer lemon (C. volkameriana Pasquale), and Palestine sweet lime (C. limettioides Tan.) rootstocks are typical of citrus trees with extensive root structure in which $50 \%$ of the fibrous

Received for publication 28 Mar. 2006. Accepted for publication 28 Sept. 2006. We acknowledge the financial support of The Florida Department of Agriculture and Consumer Services and the efforts of Marjie Cody, Tom Graham, and Amanda Myers without whom this research would not have been possible.

${ }^{1}$ Corresponding author. E-mail: ktm@ifas.ufl.edu. roots were at soil depths greater than $0.7 \mathrm{~m}$. Large, highyielding trees with extensive root systems dominated the citrus industry in Florida when trees were irrigated less intensively and planted at much lower densities. Unfortunately, rough lemon has been virtually eliminated as a commercial rootstock as a result of citrus blight disease (unknown etiology) in the 1970s and 1980s (Castle, 1980). Carrizo citrange and Swingle citrumelo are examples of the intensive-type root systems with few fibrous roots below $0.7 \mathrm{~m}$ and less lateral development (Castle and Krezdorn, 1975). These rootstocks now dominate the Florida citrus industry and are well suited for high-density, intensively managed plantings (Castle, 1978).

Little root density distribution data exist for citrus relative to increase in tree size. Fibrous root dry weight density ranged between 300 and $1200 \mathrm{~g} \cdot \mathrm{m}^{-3}$ depending on rootstock, distance from the tree, and soil depth (Castle, 1978, 1980). Maximum fibrous root length density (FRLD) ranged from $0.53 \mathrm{~cm} \cdot \mathrm{cm}^{-3}$ for Swingle citrumelo to $2.02 \mathrm{~cm} \cdot \mathrm{cm}^{-3}$ for trifoliate orange (P. trifoliata) (Eissenstat, 1991). Fibrous root dry weight density in the 0 - to $0.3-\mathrm{m}$ soil depth increased from 450 to $1000 \mathrm{~g} \cdot \mathrm{m}^{-3}$ between trees when the in-row distance decreased from 4.5 to $2.5 \mathrm{~m}$ (Elezaby, 1989). He attributed the root density increase to overlapping root systems. Eissenstat et al. (1999) found that water and nutrient uptake of citrus to be a function of FRLD and soil water content. Root water and solutes uptake modeling is commonly based on incorporating spatial root distribution and root length or root length density (Chandra and Rai, 1996; Hayhoe, 1981; Mmolawa and Or, 2000).

Fibrous root weight distribution in the previously mentioned references related to tree age, but relationships between fibrous root dry weight or FRLD to tree size have not been described. 


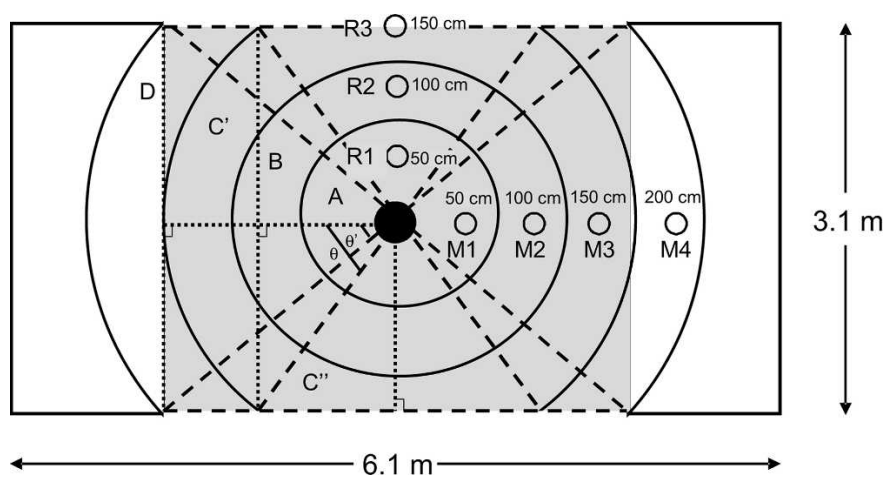

Fig. 1. Diagram of the ground surface area allocated to a single citrus tree in the orchard with trees spaced $3.1 \times 6.1 \mathrm{~m}$. The shaded area is the ground surface covered by the hedgerow tree canopy. Small circles indicate relative position of in-row (R1, R2, R3) and cross-row (M1, M2, M3, M4) where root density samples were collected. Large circles define the boundaries between root zone sections A, B, C, and D. Dashed lines define the root zone into portions of circle $C^{\prime}$ and $D$ with angles $\theta$ and $\theta^{\prime}$, respectively, and triangles $C^{\prime \prime}$. Dotted lines define perpendicular lines used in determining angles $\theta$ and $\theta^{\prime}$.

Many factors such as rootstock, soil type, irrigation practices, and nutritional status can contribute to trees of the same age differing in tree size. Thus, tree age is probably not a reliable index on which to base root distribution relationships. Therefore, the following hypotheses were tested: 1) root distribution of similar sized trees is significantly affected by rootstock, 2) distributions of FRLD are similar for trees of similar size grown on the same soil type and rootstock, and 3) generic relationships can be developed for well-drained soils that describe citrus root densities at various depths from the soil surface and distances from the tree as a function of tree size. To test these hypotheses, we determined spatial FRLD distribution with respect to lateral distance away from the tree trunk and soil depth for mature 'Hamlin' orange trees grown on two commercial citrus rootstocks. We also developed relationships that define FRLD of fibrous roots at various soil positions within the root zone as a function of tree size. A relationship of vertical and horizontal FRLD distribution to tree size could then be used to estimate spatial FRLD distribution for citrus water and nutrient uptake models.

\section{Materials and Methods}

Tree AND SITE ChaRaCteristics. FRLD distribution was determined for three sets of citrus trees grown on sandy soils typical of central Florida's citrus-producing region.

We examined the root systems of two sets of six randomly selected mature 'Hamlin' orange trees each in Feb. 2001 and Jan. 2002 from a commercial citrus grove near Winter Garden in western Orange County, Fla. (lat. $28^{\circ} 57^{\prime} \mathrm{N}$, long. $81^{\circ} 55^{\prime} \mathrm{W}$ ). Each set was comprised of 14-year-old trees planted in 1987 at a spacing of $3 \mathrm{~m}$ in-row and $6.1 \mathrm{~m}$ between rows. Three trees of each set were on Swingle citrumelo rootstock and the remaining three on Carrizo citrange rootstock. All trees had been fertilized with $240 \mathrm{~kg} \cdot \mathrm{ha}^{-1} \mathrm{~N}$ per year for the previous 5 years through a microirrigation system. Trees were irrigated with reclaimed wastewater containing nitrate nitrogen $\left(\mathrm{NO}_{3}-\mathrm{N}\right)$ at $\approx 7 \mathrm{mg} \cdot \mathrm{L}^{-1}$.

A third set of six 'Valencia' orange trees on Swingle citrumelo rootstock of various sizes were randomly selected in a grove near Fort Meade in southern Polk County, Fla. (lat. $27^{\circ} 46^{\prime} \mathrm{N}$, long. $81^{\circ} 81^{\prime} \mathrm{W}$ ) and were sampled in Oct. 2001. Trees in this grove were planted intermittently during the previous 20 years, resulting in trees of widely ranging canopy volume. The trees had been fertilized with dry soluble fertilizer three or more times per year and were irrigated with wellwater using a low-volume microsprinkler system. All three sets of trees were grown in a commercial citrus orchard setting with trees of similar age, size, and condition adjacent to the trees in both in-row and between-row directions. The larger trees (canopy volume greater than $20 \mathrm{~m}^{3}$ ) had been pruned to form a hedgerow.

The soil series at the Orange County site was Candler fine sand (hyperthermic, uncoated, Typic Quartzipsamment) and at the Polk county site was Zolfo fine sand (sandy siliceous, hyperthermic Grossarenic Entic Haplohumod). These two soils are typical of the central Florida ridge and have field capacity water content of 0.06 to $0.08 \mathrm{~m}^{3} \cdot \mathrm{m}^{-3}$ in the upper $1 \mathrm{~m}$. The Candler series consists of excessively drained, highly permeable soils formed from marine sediments located in upland areas with slopes from $0 \%$ to $12 \%$. The $\mathrm{A}$ and $\mathrm{E}$ horizons consist of single-grained fine sand (greater than 96\%), have a loose texture, and are strongly acidic. A Bt horizon is located $2 \mathrm{~m}$ deep or more and includes loamy lamellae 0.1 to $3.5 \mathrm{~cm}$

Table 1. Mature 'Hamlin' orange tree mean fibrous root length density, estimated root length, and percentage of root system in the upper $0.9 \mathrm{~m}$ of soil by rootstock and soil depth.

\begin{tabular}{|c|c|c|c|c|c|c|}
\hline \multirow[b]{2}{*}{ Soil depth $(\mathrm{cm})$} & \multicolumn{3}{|c|}{ Carrizo citrange } & \multicolumn{3}{|c|}{ Swingle citrumelo } \\
\hline & $\begin{array}{l}\text { FRLD }^{\mathrm{z}} \\
\left(\mathrm{cm} \cdot \mathrm{cm}^{3}\right)\end{array}$ & $\begin{array}{l}\text { Root length }^{y} \\
\text { (m) }\end{array}$ & $\begin{array}{l}\text { Root length } \\
0-90 \mathrm{~cm}^{\mathrm{z}}(\%)\end{array}$ & $\begin{array}{l}\text { FRLD }^{z} \\
\left(\mathrm{~cm} \cdot \mathrm{cm}^{3}\right)\end{array}$ & $\begin{array}{l}\text { Root length } \\
\text { (m) }\end{array}$ & 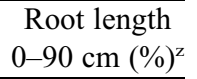 \\
\hline $0-15^{\mathrm{x}}$ & $0.84 \mathrm{~A}$ & 432 & $38 \mathrm{~A}$ & $1.39 \mathrm{~A}$ & 620 & $53 \mathrm{~A}$ \\
\hline $30-45$ & $0.16 \mathrm{~B}$ & 82 & $7 \mathrm{C}$ & $0.16 \mathrm{~B}$ & 85 & $7 \mathrm{C}$ \\
\hline $45-60$ & $0.28 \mathrm{~B}$ & 155 & $14 \mathrm{~B}$ & $0.19 \mathrm{~B}$ & 88 & $8 \mathrm{C}$ \\
\hline $60-75$ & $0.32 \mathrm{~B}$ & 176 & $16 \mathrm{~B}$ & $0.21 \mathrm{~B}$ & 118 & $10 \mathrm{~B}$ \\
\hline
\end{tabular}

${ }^{\mathrm{z} F i b r o u s ~ r o o t ~ l e n g t h ~ d e n s i t y ~(F R L D) ~ f o r ~ m a t u r e ~ ' H a m l i n ' ~ o r a n g e ~ t r e e s ~ e x t r a c t e d ~ f r o m ~ s o i l ~ s a m p l e s ~ a t ~ 15-c m ~ i n c r e m e n t s . ~ M e a n ~}(\mathrm{n}=6)$ separation by Duncan's multiple range test. Values followed by different letter within a column are significantly different $(P<0.05)$ from other values in the same column.

${ }^{y}$ Calculated root length from mean FRLD, tree space area $\left(3.0 \times 6.1 \mathrm{~m}, 18.3 \mathrm{~m}^{2}\right)$, and soil layer depth.

${ }^{x}$ FRLD and proportion of root length for 'Hamlin' orange trees at the 0 - to $15-\mathrm{cm}$ depth was significantly different $(P<0.05)$ for Swingle citrumelo rootstock compared with Carrizo citrange. FRLD and proportion of root length were not significantly different by rootstock for remaining depth increments. 


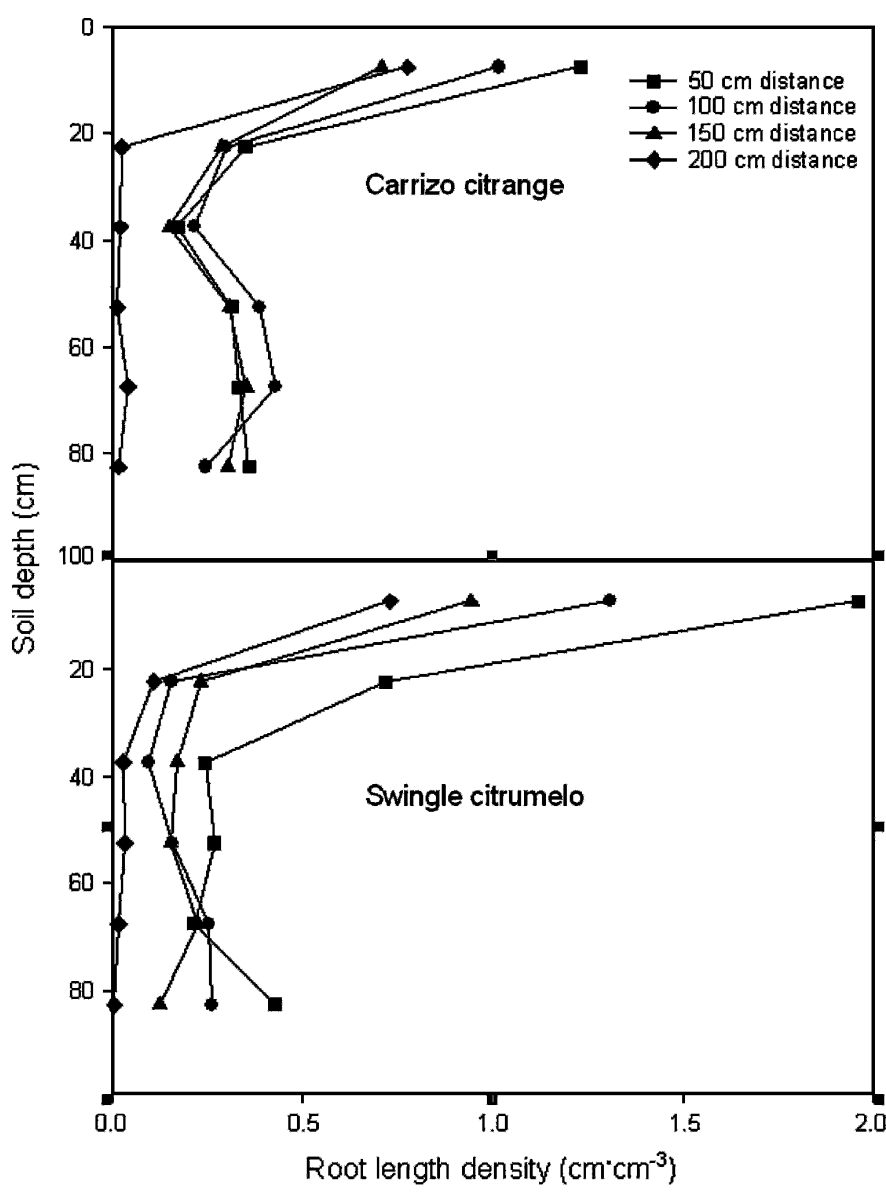

Fig. 2. Changes in fibrous root length density as a function of soil depth from the surface, and distance from the tree trunk for 'Hamlin' orange trees on (A) Carrizo citrange $(n=6)$ and $(B)$ Swingle citrumelo $(n=6)$ rootstocks.

thick and 5 to $15 \mathrm{~cm}$ long. Zolfo series soils are sandy and slightly less well drained than Candler. The A horizon consists of fine sand with single-grained (greater than 96\%), loose texture. The $\mathrm{Bh}$ horizon at a depth of greater than $1 \mathrm{~m}$ is $\approx 5 \mathrm{~cm}$ thick and consists of fine sand coated with organic matter possessing weak granular to weak fine subangular blocky structure.

ROOT LENGTH DENSITY SAMPLES. Three soil cores were removed from under each tree at $0.5-\mathrm{m}$ increments in the row to the midpoint between trees (R1, R2, and R3; Fig. 1) and four cores at $0.5-\mathrm{m}$ increments between tree rows to a distance of $2 \mathrm{~m}$ from the tree trunk (M1, M2, M3, and M4; Fig. 1). Cores were taken with a 7.6-cm-diameter bucket auger at $0.15-\mathrm{m}$ increments from 0 to $0.9 \mathrm{~m}$. Auger holes were inspected for roots that were not cleanly cut to maximize root collection. The auger was sharpened periodically as needed to remove the maximum root sample. Samples containing both root and soil were cooled on ice in the field and subsequently frozen at $-4{ }^{\circ} \mathrm{C}$. Roots were removed from thawed soil by washing though an $850-\mu \mathrm{m}$ sieve. Any debris not passing through the sieve was removed manually. Roots were subsequently separated into size categories by diameter ( $0-4 \mathrm{~mm}$ and greater than $4 \mathrm{~mm}$ ). Root length of fibrous roots less than $4 \mathrm{~mm}$ in diameter was determined using the line intersect method (Newman, 1966). FRLD was determined by dividing the sample fibrous root length by the sample soil volume.

ESTIMATED FIBROUS ROOT LENGTH. We estimated root length for the soil volumes represented by each sample distance and depth increment for each of the 18 orange trees. Soil volumes were determined using concentric rings with radii equal to the midpoints between soil sample locations (Fig. 1). The surface area of ring A (Fig. 1) was determined by calculating the area of a circle with radii of $0.75 \mathrm{~m}$. The area of ring $\mathrm{B}$ was equal to the area of a circle with a radius of $1.25 \mathrm{~m}$ minus the area of ring A. The circles at 1.75 and $2.25 \mathrm{~m}$ from the tree trunks for samples at 1.5 and $2 \mathrm{~m}$, respectively, extended beyond the tree space described by the in-row and cross-row distances of 3.1 and $6.1 \mathrm{~m}$, respectively. To account for the area within the tree space, the area of ring $\mathrm{C}$ was assumed to be twice the sum of two segments $C^{\prime}$ and $C^{\prime \prime}$ minus the area of ring B (Fig. 1). Segment $C^{\prime}$ is the $2 \theta / 360$ portion of a circle with radius of $1.75 \mathrm{~m}$ where $\theta$ has an opposite side of one-half the in-row spacing and a hypotenuse of the radius of the circle. The segment $C^{\prime \prime}$ was estimated as the product of the opposite side of a triangle with an angle equal to one-half $180-2 \theta$ and a height of one-half the in-row spacing. The area of $\mathrm{D}$ was estimated to be the $4 \theta^{\prime} / 360$ portion of a circle with a radius of $2.25 \mathrm{~m}$ minus the same portion of a circle using the same angle and a diameter of $1.75 \mathrm{~m}$ where $\theta$ ' was determined assuming an opposite side of one-half the in-row spacing and a hypotenuse of the radius of the circle. This estimate slightly underestimates the area of D by $\approx 2.5 \%$. The volume of soil used to determine the estimated root length at each sampling point was the product of the area of the ring determined by the sampling distance and the $0.15-\mathrm{m}$ sampling increment.

Table 2. Mature 'Hamlin' orange tree mean fibrous root length density, estimated root length, and percentage of root system in the upper $0.9 \mathrm{~m}$ of soil by rootstock and distance from the tree trunk.

\begin{tabular}{|c|c|c|c|c|c|c|}
\hline \multirow[b]{2}{*}{$\begin{array}{l}\text { Distance from } \\
\text { trunk }(\mathrm{cm})\end{array}$} & \multicolumn{3}{|c|}{ Carrizo citrange } & \multicolumn{3}{|c|}{ Swingle citrumelo } \\
\hline & $\begin{array}{l}\text { FRLD }^{\mathrm{z}} \\
\left(\mathrm{cm} \cdot \mathrm{cm}^{3}\right)\end{array}$ & $\begin{array}{l}\text { Root length }^{y} \\
\text { (m) }\end{array}$ & $\begin{array}{c}\text { Root length } \\
0-225 \mathrm{~cm}^{\mathrm{z}}(\%)\end{array}$ & $\begin{array}{l}\text { FRLD }^{\mathrm{z}} \\
\left(\mathrm{cm} \cdot \mathrm{cm}^{3}\right)\end{array}$ & $\begin{array}{l}\text { Root length } \\
(\mathrm{cm})\end{array}$ & $\begin{array}{c}\text { Root length } \\
0-225 \mathrm{~cm}^{\mathrm{z}}(\%)\end{array}$ \\
\hline $0-75^{\mathrm{x}}$ & $0.39 \mathrm{~A}$ & 100 & $15 \mathrm{~A}$ & $0.64 \mathrm{~A}$ & 163 & $25 \mathrm{~A}$ \\
\hline $125-175$ & $0.34 \mathrm{AB}$ & 310 & $45 \mathrm{~A}$ & $0.29 \mathrm{AB}$ & 248 & $38 \mathrm{~A}$ \\
\hline $175-225$ & $0.17 \mathrm{~B}$ & 78 & $11 \mathrm{~B}$ & $0.15 \mathrm{~B}$ & 70 & $11 \mathrm{~B}$ \\
\hline
\end{tabular}

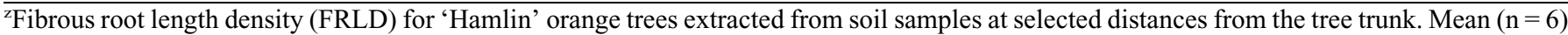
separation by Duncan's multiple range test. Values followed by different letter within a column are significantly different $(P<0.05)$ from other values in the same column.

${ }^{\mathrm{y}}$ Calculated root length from mean FRLD, tree space area $\left(3.0 \times 6.1 \mathrm{~m}, 18.3 \mathrm{~m}^{2}\right)$, and soil layer depth.

'FRLD for 'Hamlin' orange trees at the 0 - to $75-\mathrm{cm}$ distance was significantly different $(P<0.05)$ for Swingle citrumelo rootstock compared with Carrizo citrange. FRDL was not significantly different by rootstock for remaining distances. 
Table 3. Proportion of total estimated root length of 'Valencia' orange trees of various canopy volumes and mature 'Hamlin' orange trees to $0.9 \mathrm{~m}$ by soil depth.

\begin{tabular}{lrrrrrrr}
\hline $\begin{array}{c}\text { Soil depth } \\
\text { (cm) }\end{array}$ & \multicolumn{7}{c}{ Tree canopy volume $\left(\mathrm{m}^{3}\right)$} \\
\cline { 2 - 8 } & 2.4 & 3.2 & 10.7 & 13.3 & 16.9 & 28.4 & $34.3^{\mathrm{z}}$ \\
\hline \multicolumn{7}{c}{ Proportion of total } & estimated root length $(\%)^{\mathrm{y}}$ \\
$0-15$ & 56.1 & 59.2 & 53.4 & 58.9 & 38.8 & 40.3 & 43.9 \\
$15-30$ & 27.1 & 18.4 & 24.8 & 24.1 & 26.3 & 19.5 & 12.7 \\
$30-45$ & 8.1 & 7.8 & 13.3 & 8.5 & 12.1 & 13.7 & 7.2 \\
$45-60$ & 4.9 & 6.7 & 5.0 & 4.0 & 11.0 & 15.0 & 11.1 \\
$60-75$ & 3.1 & 6.9 & 3.1 & 4.0 & 7.1 & 7.2 & 13.5 \\
$75-90$ & 0.7 & 1.0 & 0.4 & 0.6 & 4.7 & 4.2 & 11.6
\end{tabular}

${ }^{\mathrm{z}}$ Mean $(\mathrm{n}=12)$ values of mature 'Hamlin' orange tree study (standard deviation $=2.3$ ).

${ }^{\mathrm{y}}$ Significant canopy volume $\times$ depth interaction $(P<0.01)$.

Tree Size Measurement. Tree canopy volume (TCV) and trunk cross-sectional areas (TCSA) of each tree were estimated to compare root length density with a measure of tree size. Canopy diameter of each tree was measured $1.5 \mathrm{~m}$ above the ground within and across the row. Tree height and hedgerow intercept measurements were made using a $5-\mathrm{m}$ graduated pole. Hedgerow intercept was the height from the ground to the point at which the canopies of two trees meet in the row. These measurements have been used by Whitney et al. (1991) to determine TCV based on a spheroid model. Trunk diameter $0.05 \mathrm{~m}$ above the ground was measured in both within-row and across-row directions. TCSA was determined for each tree assuming an elliptic shape.

Data ANaLysis. Density data from samples collected from each of two sets of six mature 'Hamlin' trees were analyzed by analysis of variance using the general linear model procedure of SAS (SAS Institute, Cary, N.C.) to determine withinyear variation. Year was used as a covariant to determine variation among years. The relationship of FRLD estimated from soil samples collected from all three sets of trees to individual tree TCV and TCSA was analyzed using linear regression analysis in SAS. Regression equations were determined with SigmaPlot software (SPSS, Chicago).

\section{Results and Discussions}

Mature 'Hamlin' ORANGe tree ROOT Distribution. Fibrous root length density was not significantly different $(P>0.05)$

Table 4. Proportion of total estimated root length to $0.9 \mathrm{~m}$ for 'Valencia' orange trees of various canopy volumes and mature 'Hamlin' orange trees by distance from the tree trunk.

\begin{tabular}{|c|c|c|c|c|c|c|c|}
\hline \multirow{2}{*}{$\begin{array}{l}\text { Distance from } \\
\text { tree }(\mathrm{cm})\end{array}$} & \multicolumn{7}{|c|}{ Tree canopy volume $\left(\mathrm{m}^{3}\right)$} \\
\hline & 2.4 & 3.2 & 10.7 & 13.3 & 16.9 & 28.4 & $34.3^{2}$ \\
\hline & \multicolumn{7}{|c|}{ Proportion of total estimated root length $(\%)^{y}$} \\
\hline $0-75$ & 64.1 & 68.0 & 58.6 & 59.8 & 41.4 & 34.6 & 18.7 \\
\hline $75-125$ & 33.8 & 29.7 & 38.9 & 38.0 & 40.6 & 26.9 & 27.5 \\
\hline $125-175$ & 2.0 & 2.3 & 2.4 & 2.1 & 17.5 & 32.7 & 42.8 \\
\hline $175-225$ & 0.0 & 0.0 & 0.0 & 0.0 & 0.5 & 5.8 & 11.0 \\
\hline
\end{tabular}

$\overline{{ }^{\mathrm{z}} \text { Mean }(\mathrm{n}=12) \text { values of mature 'Hamlin' orange tree study (standard }}$ deviation $=3.4$ ).

${ }^{\mathrm{y}}$ Significant canopy volume $\times$ distance interaction at $P<0.01$.
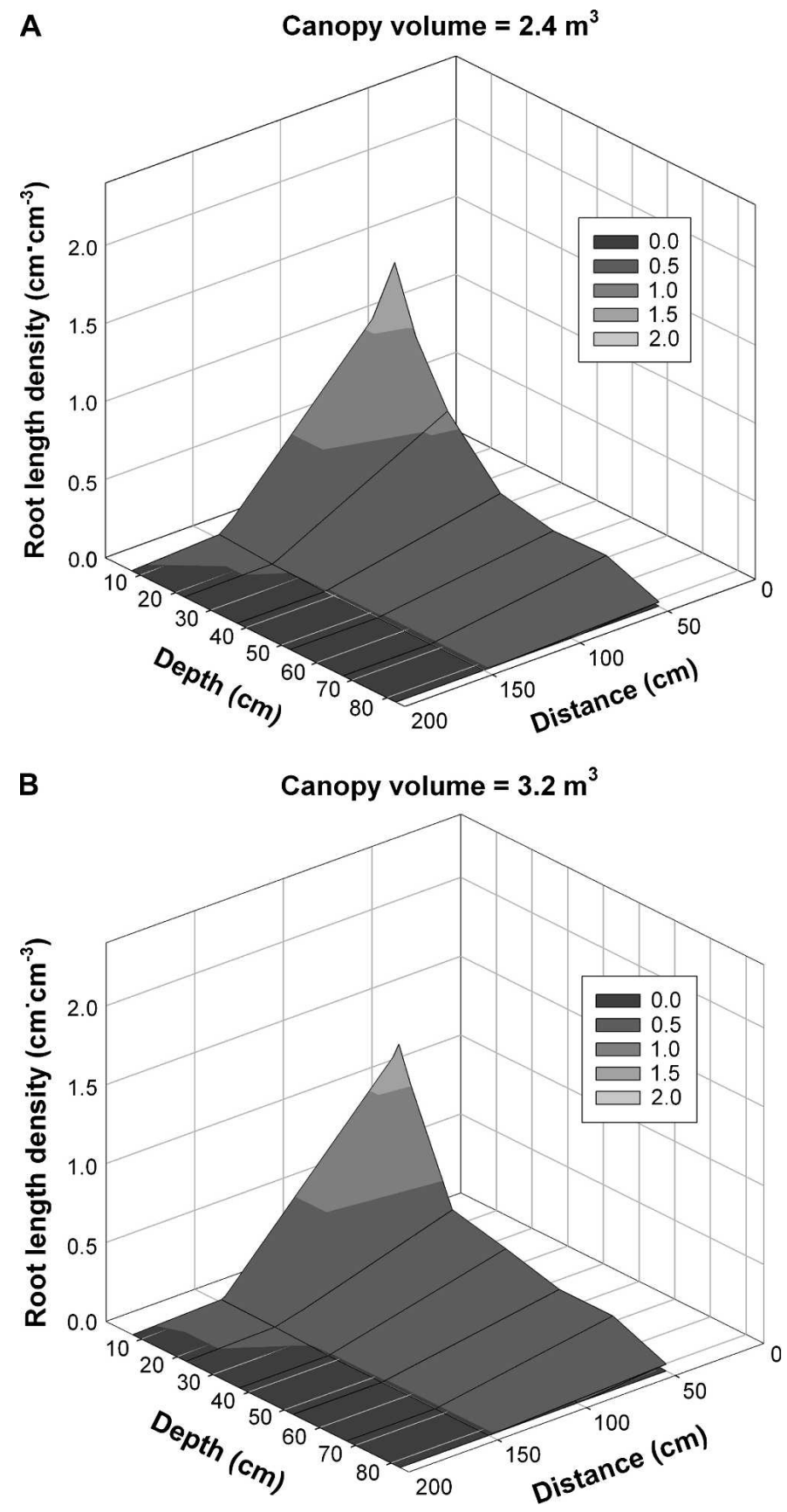

Fig. 3. Distribution of 'Valencia' orange tree fibrous root length density with soil depth and distance from the tree trunk for 2- to 5-year-old trees with average canopy volume of (A) $2.4 \mathrm{~m}^{3}$ and (B) $3.2 \mathrm{~m}^{3}$.

among years indicating little year-to-year change in mature 'Hamlin' orange tree root length density once containment size is obtained. Therefore, the FRLDs were pooled $(n=12)$ and analyzed for interactions among rootstock, soil depth, and distance from the tree trunk. Although average FRLD to a $0.9-\mathrm{m}$ depth for the tree allocated space was not statistically significant $(P<0.05)$ between rootstocks $(0.36$ and 0.41 $\mathrm{cm} \cdot \mathrm{cm}^{-3}$ soil for Carrizo citrange and Swingle citrumelo, respectively), a significant interaction $(P<0.01)$ of rootstock and depth suggests distinctly different root distribution patterns between the two rootstocks. Trees on Swingle had significantly 
A

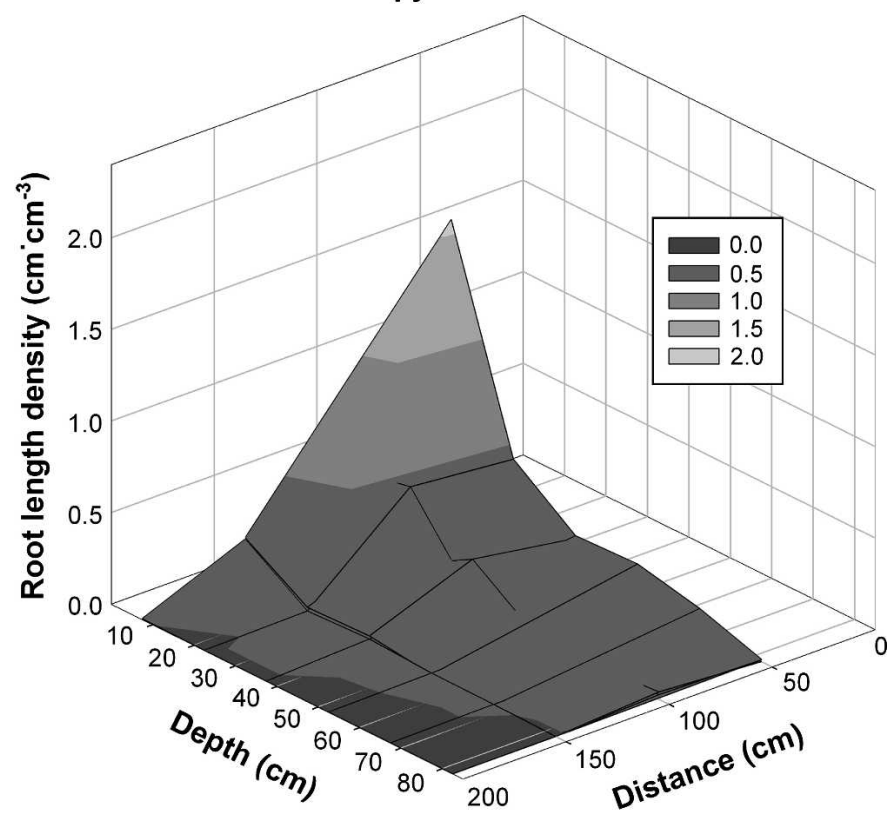

B

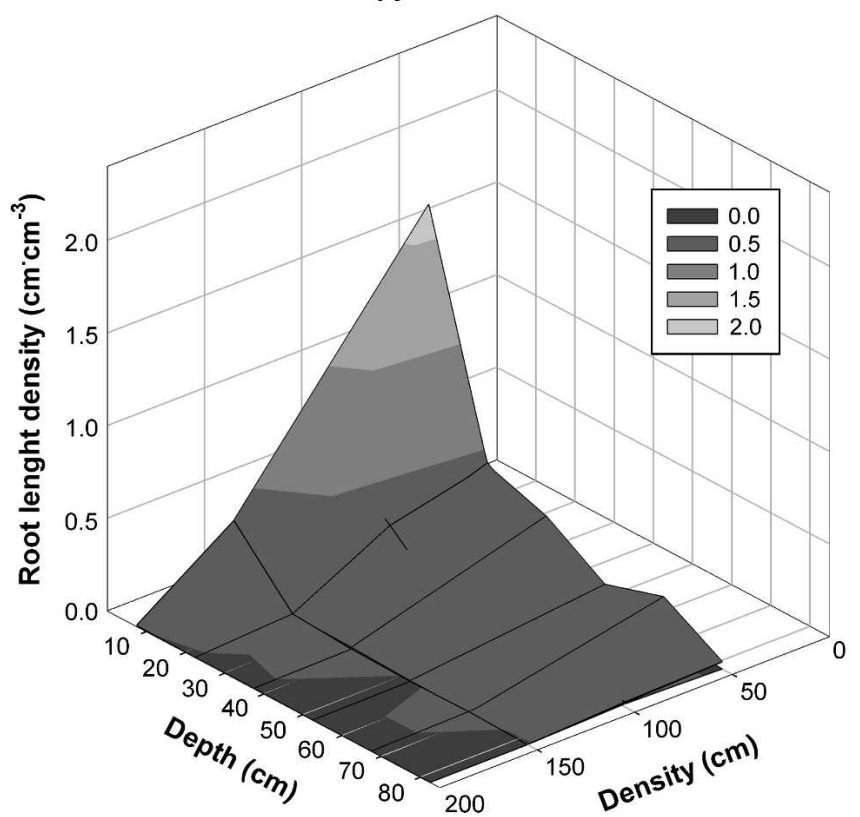

Fig. 4. Distribution of 'Valencia' orange tree fibrous root length density with soil depth and distance from the tree trunk for 5- to 10-year-old trees with average canopy volume of (A) $10.7 \mathrm{~m}^{3}$ and (B) $13.3 \mathrm{~m}^{3}$.

greater $(P<0.05)$ FRLD near the soil surface than trees on Carrizo citrange (Table 1); however, FRLD in the top $0.15 \mathrm{~m}$ ranged from 0.9 to $2.0 \mathrm{~cm} \cdot \mathrm{cm}^{-3}$ soil at a distance of $1.5 \mathrm{~m}$ or less for trees on Swingle citrumelo, whereas FRLD ranged from 0.7 to $1.2 \mathrm{~cm} \cdot \mathrm{cm}^{-3}$ at the same depth and distance for trees on Carrizo citrange. Mean FRLD decreased to $0.16 \mathrm{~cm} \cdot \mathrm{cm}^{-3}$ for both rootstocks at the 0.30 - to $0.45-\mathrm{m}$ depth and increased to 0.6 to $0.75 \mathrm{~m}$ depth (Fig. 2). In a similar study on root density of apples (Malus pumila Mill.), Sharma and Chauham (2005) found nearly all fibrous roots above the 50 -cm depth with very few roots between 75 and $100 \mathrm{~cm}$.
A Canopy volume $=16.9 \mathrm{~m}^{3}$
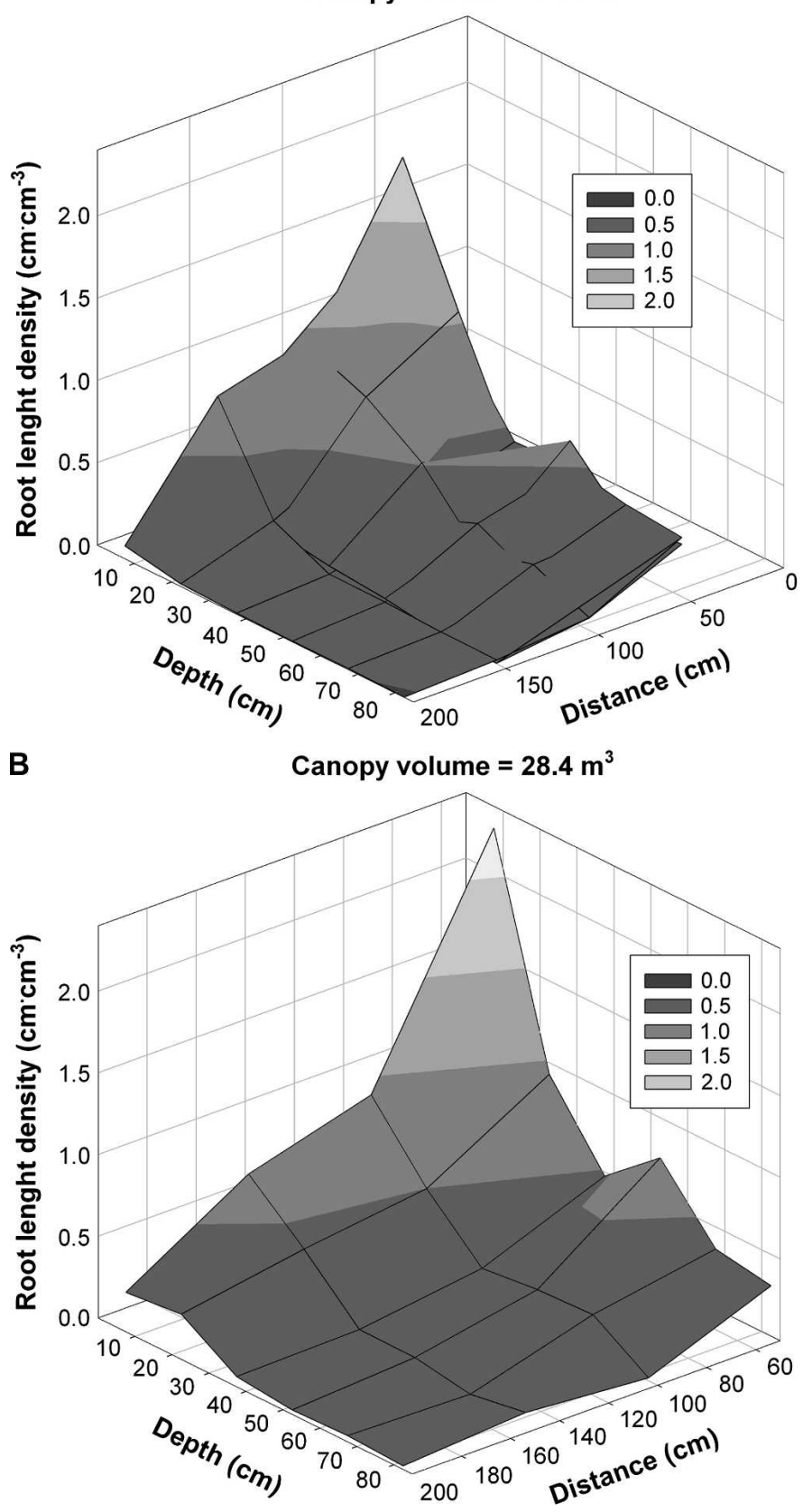

Fig. 5. Distribution of 'Valencia' orange tree fibrous root length density with soil depth and distance from the tree trunk for 10- to 15- and greater than 15 -year-old trees with average canopy volume of (A) $16.9 \mathrm{~m}^{3}$ and (B) $28.4 \mathrm{~m}^{3}$.

The FRLD distribution among the 12 mature 'Hamlin' trees was similar to the intensive distribution described by Castle and Krezdorn (1975) with $50 \%$ to $66 \%$ of the total fibrous roots $0.9 \mathrm{~m}$ deep or less within the upper $0.30 \mathrm{~m}$ and few fibrous roots below $0.75 \mathrm{~m}(10 \%)$. Lateral fibrous roots were less developed in mature trees on both rootstocks with $\approx 11 \%$ of fibrous roots beyond $1.75 \mathrm{~m}$ from the tree trunk. Hassan (1984) reported similar root density distribution for Swingle citrumelo and an unnamed citrange. Finding a similarly high proportion of fibrous roots and nutrient uptake in the upper $0.5 \mathrm{~m}$ of soil, Thakur et al. (1981) concluded that "citrus is basically a surface feeder." We found the upper $0.45 \mathrm{~m}$ of soil contained $\approx 76 \%$ of 
Table 5. Regression coefficients and statistics for 'Valencia' and 'Hamlin' orange tree fibrous root length density as a function of distance from the tree trunk and soil depths by tree canopy volume using a third-order polynomial model ${ }^{\mathrm{z}}$.

\begin{tabular}{|c|c|c|c|c|c|c|c|c|}
\hline $\begin{array}{l}\text { Distance from } \\
\text { trunk }(\mathrm{cm})\end{array}$ & Depth $(\mathrm{cm})$ & $\mathrm{Y}_{0}$ & $\mathrm{a}$ & $\mathrm{b}$ & $\mathrm{c}$ & $r^{2}$ & $\operatorname{RMSE}\left(\mathrm{cm} \cdot \mathrm{cm}^{-3}\right)$ & $P$ \\
\hline 50 & $15-30$ & 0.99 & 0.289 & 0.027 & 0.0006 & 0.78 & 0.15 & 0.005 \\
\hline 50 & $45-60$ & 0.45 & 0.160 & 0.015 & 0.00003 & 0.83 & 0.12 & 0.002 \\
\hline 50 & $60-75$ & 0.29 & 0.099 & 0.009 & 0.00002 & 0.68 & 0.09 & 0.022 \\
\hline 50 & $75-90$ & 0.31 & 0.140 & 0.013 & 0.0003 & 0.88 & 0.06 & 0.0005 \\
\hline 100 & $30-45$ & 0.19 & 0.069 & 0.007 & 0.00002 & 0.48 & 0.14 & 0.14 \\
\hline 100 & $45-60$ & 0.20 & 0.082 & 0.008 & 0.00002 & 0.82 & 0.05 & 0.002 \\
\hline 100 & $60-75$ & 0.071 & 0.068 & 0.006 & 0.00001 & 0.85 & 0.04 & 0.001 \\
\hline 100 & $75-90$ & 0.040 & 0.018 & 0.002 & 0.00001 & 0.51 & 0.04 & 0.107 \\
\hline 150 & $0-15$ & 0.17 & 0.087 & 0.011 & 0.0001 & 0.97 & 0.06 & $<0.0001$ \\
\hline 150 & $75-90$ & 0.008 & 0.004 & 0.0003 & 0.000001 & 0.65 & 0.01 & 0.030 \\
\hline 200 & $0-15$ & 0.042 & 0.020 & 0.002 & 0.0001 & 0.99 & 0.01 & 0.014 \\
\hline 200 & $15-30$ & 0.013 & 0.007 & 0.001 & 0.0001 & 0.99 & 0.01 & $<0.0001$ \\
\hline 200 & $30-45$ & 0.0003 & 0.001 & 0.0001 & 0.00001 & 0.99 & 0.01 & $<0.0001$ \\
\hline 200 & $45-60$ & 0.002 & 0.001 & 0.0001 & 0.00001 & 0.99 & 0.01 & 0.004 \\
\hline 200 & $60-75$ & 0.003 & 0.001 & 0.0001 & 0.000001 & 0.99 & 0.01 & 0.004 \\
\hline 200 & $75-90$ & 0.001 & 0.001 & 0.0001 & 0.00001 & 0.99 & 0.01 & 0.0002 \\
\hline
\end{tabular}

${ }^{\mathrm{z}} \mathrm{Y}=\mathrm{Y}_{0}+\mathrm{aX}+\mathrm{bX} \mathrm{X}^{2}+\mathrm{cX}$, where $\mathrm{X}=\mathrm{TCV}$ and $\mathrm{Y}_{0}, \mathrm{a}, \mathrm{b}$, and $\mathrm{c}$ are regression coefficients.

$\mathrm{RMSE}=$ root mean square error; $\mathrm{TCV}=$ tree canopy volume.

Swingle citrumelo fibrous root length. This compares well with a study by Mikhail and El-Zefhoui (1979) who found that 79\% of total fibrous root weight of 'Valencia' oranges occurred in the first $0.60 \mathrm{~m}$ of soil on sandy soils, whereas clay soils contained $94 \%$ in the same depth. However, trees grown on Carrizo citrange had more FRLD deeper than $0.45 \mathrm{~m}$ compared with trees grown on Swingle citrumelo, resulting in only $58 \%$ of Carrizo tree root length above the $0.45-\mathrm{m}$ depth (Table 1).

Unlike soil depth, we found that distance from the tree trunk had less effect on distribution of fibrous roots among rootstocks (Table 2). Swingle citrumelo had significantly greater $(P<$ $0.05)$ FRLD $0.5 \mathrm{~m}$ from the trunk and a greater proportion of root length 0 to $75 \mathrm{~cm}$ from the trunk compared with trees on Carrizo citrange. However, trees on Carrizo citrange had greater FRLD and proportion of root length greater than $1 \mathrm{~m}$ from the tree trunk than Swingle citrumelo. Nearly $90 \%$ of the estimated total root length of both rootstocks was within $1.75 \mathrm{~m}$ of the trunk. This distance corresponds roughly to the extent of both the tree canopy and the irrigated zone (Fig. 1). Sharma and Chauham (2005) found $80 \%$ of total fibrous roots of mature apple trees within a 2-m diameter were between 50 and $150 \mathrm{~cm}$ from the tree trunk. Plessis and Smith (1973) found $80 \%$ of the fibrous roots under the canopy for mango (Mangifera indica $\mathrm{L}$.).

Citrus FRLD in the top $0.15 \mathrm{~m}$ was generally greater in the in-row orientation than in the cross-row orientation (data not shown). Previous studies have concluded the increase in inrow FRLD was most likely the result of overlap from the adjacent tree (Kaufmann et al., 1992; Whitney et al., 1991). In-row and cross-row FRLDs averaged to the 0.9 -m depth were 0.41 and $0.35 \mathrm{~cm} \cdot \mathrm{cm}^{-3}$, respectively, and were not significantly different $(P<0.05)$ as a result of high variability in the data. Average FRLD $0.5 \mathrm{~m}$ from the trunk in the crossrow orientation decreased more gradually than did FRLD 1, 1.5 , and $2 \mathrm{~m}$ away. Minimum FRLD in the in-row orientation occurred at the 0.45 - to $0.6-\mathrm{m}$ depth for the $0.5-\mathrm{cm}$ distance as opposed to the 0.3 - to $0.45-\mathrm{cm}$ depth for the $1-, 1.5-$, and $2-\mathrm{m}$ distances. Citrus FRLD increased at the 0.6- to $0.75-\mathrm{m}$ depth for the 1 - and $1.5-\mathrm{m}$ distances and $0.75-$ to $0.9-\mathrm{m}$ depth for the $0.5-\mathrm{cm}$ distance.

The differences we found in FRLD between rootstocks indicate that irrigation depth and the depth for fertilizer placement based on root distribution should be rootstockspecific. Thus, mature citrus trees on Swingle citrumelo rootstock should be irrigated to a shallower depth compared with trees on Carrizo citrange. Deep irrigation beyond $0.45 \mathrm{~m}$ for Swingle citrumelo or $0.6 \mathrm{~m}$ for Carrizo citrange in these soils will waste water and greatly increase the risk of leaching soil $\mathrm{N}$ below the effective root zone, potentially decreasing nutrient use efficiency.

ROOT LENGTH DENSITY DISTRIBUTION AS A FUNCTION OF TREE SIzE. Citrus FRLD was significantly different $(P<0.01)$ for both soil depth (Table 3 ) and distance from the tree trunk (Table 4) across a wide range of tree sizes $\left(3 \mathrm{~m}^{3}\right.$ less than TCV less than $\left.35 \mathrm{~m}^{3}\right)$. Linear regressions of FRLD and root length proportion were significant $(P<0.01)$ with a negative slope for both the 0 to $0.15 \mathrm{~m}$ and 0.15 to $0.30 \mathrm{~m}$ soil layers indicating a reduction in root length proportion with increased tree size. The proportion of root length in the top $0.15 \mathrm{~m}$ decreased from 
Table 6. Regression coefficients and statistics for 'Valencia' and 'Hamlin' orange tree fibrous root length density as a function of distance from the tree trunk and soil depths by tree cross-sectional area using a third-order polynomial model. ${ }^{\mathrm{z}}$

\begin{tabular}{|c|c|c|c|c|c|c|c|c|}
\hline Distance $(\mathrm{cm})$ & Depth $(\mathrm{cm})$ & $\mathrm{Y}_{0}$ & $\mathrm{a}$ & $\mathrm{b}$ & $\mathrm{c}$ & $\mathrm{r}^{2}$ & $\operatorname{RMSE}\left(\mathrm{cm} \cdot \mathrm{cm}^{-3}\right)$ & $P$ \\
\hline 50 & $0-15$ & 0.41 & 0.001 & 0.00005 & 0.00001 & 0.71 & 0.44 & 0.015 \\
\hline 50 & $15-30$ & 0.24 & 0.0001 & 0.00003 & 0.00001 & 0.56 & 0.21 & 0.071 \\
\hline 50 & $30-45$ & 0.04 & 0.0001 & 0.00001 & 0.00001 & 0.68 & 0.09 & 0.022 \\
\hline 50 & $60-75$ & 0.08 & 0.0001 & 0.00002 & 0.00002 & 0.66 & 0.09 & 0.027 \\
\hline 50 & $75-90$ & 0.20 & 0.0002 & 0.00003 & 0.00001 & 0.79 & 0.08 & 0.004 \\
\hline 100 & $0-15$ & 0.23 & 0.00001 & 0.00001 & 0.00001 & 0.67 & 0.19 & 0.026 \\
\hline 100 & $30-45$ & 0.42 & 0.0004 & 0.00003 & 0.00002 & 0.52 & 0.13 & 0.099 \\
\hline 100 & $45-60$ & 0.17 & 0.0002 & 0.00002 & 0.00002 & 0.82 & 0.05 & 0.003 \\
\hline 100 & $60-75$ & 0.15 & 0.0002 & 0.00002 & 0.00001 & 0.90 & 0.03 & 0.0002 \\
\hline 100 & $75-90$ & 0.20 & 0.0002 & 0.00001 & 0.00001 & 0.97 & 0.01 & $<0.0001$ \\
\hline 150 & $0-15$ & 0.50 & 0.0004 & 0.00001 & 0.00002 & 0.96 & 0.07 & $<0.0001$ \\
\hline 150 & $15-30$ & 0.30 & 0.0003 & 0.00003 & 0.00001 & 0.83 & 0.06 & 0.002 \\
\hline 200 & $0-15$ & 0.28 & 0.0002 & 0.00003 & 0.00001 & 0.94 & 0.04 & 0.086 \\
\hline 200 & $15-30$ & 0.33 & 0.0003 & 0.00003 & 0.00001 & 0.78 & 0.08 & 0.311 \\
\hline 200 & $30-45$ & 0.07 & 0.0001 & 0.00001 & 0.00001 & 0.80 & 0.02 & 0.282 \\
\hline 200 & $45-60$ & 0.03 & 0.00001 & 0.00003 & 0.00001 & 0.87 & 0.01 & 0.192 \\
\hline 200 & $60-75$ & 0.04 & 0.00001 & 0.00004 & 0.00001 & 0.88 & 0.01 & 0.180 \\
\hline 200 & $75-90$ & 0.03 & 0.00001 & 0.00002 & 0.00001 & 0.79 & 0.01 & 0.293 \\
\hline
\end{tabular}

${ }^{\mathrm{z}} \mathrm{Y}=\mathrm{Y}_{0}+\mathrm{aX}+\mathrm{bX} \mathrm{X}^{2}+\mathrm{cX} \mathrm{X}^{3}$, where $\mathrm{X}=\mathrm{TXA}$, and $\mathrm{Y}_{0}, \mathrm{a}, \mathrm{b}$, and $\mathrm{c}$ are regression coefficient.

$\mathrm{RMSE}=$ root mean square error; TXA $=$ cross-sectional area.

$\approx 60 \%$ to $\approx 45 \%$ as canopy volume increased over the same tree size range (Table 3 ). Likewise, root length proportions decreased from $27 \%$ to $13 \%$ in the 0.15 - to $0.3-\mathrm{m}$ depth with increase in tree size. Conversely, citrus FRLD increased at depths greater than $0.45 \mathrm{~m}$ with increase in TCV. Linear regressions of FRLD and tree canopy volume were significant $(P \leq 0.10)$ at depths below $0.45 \mathrm{~m}$.

Estimated root length proportion decreased near the tree trunk ( 0 to $0.75 \mathrm{~m}$ ) from $\approx 65 \%$ to $20 \%$ as TCV increased from 3 to $35 \mathrm{~m}^{3}$ (Table 4). Linear regression of FRLD and tree canopy volume for the 0 - to 0.75 -m distance from the tree trunk was significant $(P<0.01)$ with a negative slope. Root length proportion 0.75 to $1.25 \mathrm{~m}$ away from the trunk initially increased from $30 \%$ to $40 \%$ with increase in canopy volume between 3 and $17 \mathrm{~m}^{3}$ and then decreased to nearly $25 \%$ at $35 \mathrm{~m}^{3}$. Linear regressions of FRLD and proportions of total fibrous root length beyond $1.25-\mathrm{m}$ distance from the trunk versus canopy volume were all significant $(P<0.01)$ with positive slopes, indicating increasing root length proportion beyond $1.25-\mathrm{m}$ lateral distance with increased across the range of canopy volume.

Our results show that for young citrus (canopy volume less than $5 \mathrm{~m}^{3}, \approx 5$ years of age), fibrous roots developed just below the soil surface with few roots deeper than $0.50 \mathrm{~m}$ from the tree trunk (Fig. 3). As trees increased in size (canopy volume $=5-15 \mathrm{~m}^{3}, \approx 5$ and 10 years of age), fibrous roots at the soil surface developed laterally toward the dripline of the tree (Fig. 4). As trees continued to grow (canopy volume greater than $15 \mathrm{~m}^{3}, \approx 10+$ years of age), roots eventually extended to $\approx 2 \mathrm{~m}$ between tree rows and to a depth of $\approx 0.90 \mathrm{~m}$ (Fig. 5). Citrus FRLD distribution increased in two modes in
Central Florida Ridge soils. A dense root mat developed just below the soil surface with few roots deeper than $0.5 \mathrm{~m}$ at a $1.5-\mathrm{m}$ distance from the tree trunk. Once these roots became established, a second region of root growth developed below $0.3 \mathrm{~m}$ between 5 and 10 years. By the time tree age reached 10 to 15 years and the canopy was nearing full hedgerow dimensions, the bimodality of the root system described in the mature tree study was fully developed and roots extended past a depth of $0.9 \mathrm{~m}$ at all distances from the tree.

Regression coefficients are presented for a third-order polynomial relationship of TCV or TCSA as the independent variable and FRLD as the dependent variable at all depths and distances (Tables 5 and 6 ). The $\mathrm{r}^{2}$ values were greater and root mean square error and $P$ values were lower for most regressions when TCV was the independent variable (Table 5) compared with TCSA as the independent variable (Table 6), suggesting that canopy volume was a more accurate predictor of FRLD than TCSA. Although complex, the temporal development of citrus root systems appears to follow consistent patterns that can be captured in functional relationships. In most fruit tree crops, including mango, banana (Musa acuminata Culla), and guava (Psidium guajava L.), the highest root density is found directly under the tree canopy (Thakur et al., 1981). The data presented here can provide root distribution information needed to determine spatial soil water and nutrient uptake for a citrus growth model. Such a model may provide an improved assessment of both spatial and temporal trends in water and nutrient uptake by citrus trees and describe an accurate target for application of rootabsorbed chemicals. 


\section{Conclusion}

FRLD distribution of trees grown on Swingle citrumelo and Carrizo citrange rootstocks increased with soil depth and lateral distance as trees grew, resulting in mature trees with bimodal root systems. Although both rootstocks developed a dense root system within the upper $0.3 \mathrm{~m}$ of soil, roots extended beyond 1 $\mathrm{m}$ in depth. Extending sampling to greater soil depths on similar well-drained soils might be useful to more accurately depict the spatial pattern of the root zone. Trees on Swingle citrumelo developed higher FRLD near the soil surface and lower FRLD below $0.3 \mathrm{~m}$ than trees on Carrizo citrange. The relatively high $\mathrm{r}^{2}$ and low root mean square error values of the functional root length density distribution relationships developed here indicate that tree size accounts for most of the variability in FRLD with distance and depth. Thus, the original hypotheses were not rejected and a model for FRLD distribution can be developed if both tree size and rootstock are included as variables.

\section{Literature Cited}

Castle, W.S. 1978. Citrus root systems: Their structure, function, growth, and relationship to tree performance. Proc. Intl. Soc. Citriculture 1:62-69.

Castle, W.S. 1980. Fibrous root distribution of 'Pineapple' orange trees on rough lemon rootstock at three tree spacings. J. Amer. Soc. Hort. Sci. 105:478-480.

Castle, W.S. and A.H. Krezdorn. 1975. Effect of citrus rootstocks on root distribution and leaf mineral content of 'Orlando' tangelo tree. J. Amer. Soc. Hort. Sci. 100:1-4.

Chandra, S.P. and A.K. Rai. 1996. Nonlinear root-water uptake model. J. Irr. Drainage Eng. 122:198-202.

Eissenstat, D.M. 1991. On the relationship between specific root length and the rate of root proliferation: A field study using citrus rootstocks. New Phytol. 118:63-68.

Eissenstat, D.M., E.L. Whaley, A. Volder, and C.E. Wells. 1999. Recovery of citrus surface roots following prolonged exposure to dry soil. J. Expt. Bot. 50:1845-1854.

Elezaby, A.A. 1989. Physiological and biological studies on root systems of some citrus stocks, Cairo Univ., Egypt. PhD Diss.

Ford, H.W. 1954. Root distribution in relation to the water table. Proc. Fla. State Hort. Soc. 67:30-33.
Ford, H.W. 1964. The effect of rootstock, soil and soil $\mathrm{pH}$ on citrus root growth in soils subject to flooding. Proc. Fla. State Hort. Soc. 77: 41-45.

Ford, H.W. 1968. Fluctuations of the water table in drained flatwoods groves. Proc. Fla. State Hort. Soc. 81:75-79.

Ford, H.W. 1969. Water management of wetland citrus in Florida. Proc. First Intl. Citrus Symp. 3:1759-1770.

Ford, H.W. 1972. Eight years of root injury from water table fluctuations. Proc. Fla. State Hort. Sci. 85:65-68.

Hassan, M.M. 1984. Effect of citrus rootstocks on root distribution, tree growth and leaf mineral composition of 'Washington' Navel orange trees. Egyptian J. Hort. 11:201-207.

Hayhoe, H. 1981. Analysis of a diffusion model for plant root growth and an application of plant soil-water uptake. Soil Sci. 131:334-343.

Kaufmann, M.R., S.B. Boswell, and L.N. Lewis. 1992. Effect of tree spacing on root distribution of 9-year old 'Washington' Navel oranges. J. Amer. Soc. Hort. Sci. 97:204-206.

Kramer, P.J. and J.S. Boyer. 1995. Water relations of plants and soils. Academic Press, N.Y.

Mikhail, E.H. and B.M. El-Zefhoui. 1979. Effect of soil types and rootstocks on root distribution, chemical composition of leaves and yield of Valencia oranges. Aust. J. Soil Res. 17:335-342.

Mmolawa, K. and D. Or. 2000. Root zone solute dynamics under drip irrigation: A review. Plant Soil 222:163-190.

Newman, E.I. 1966. A method of estimating the total length of root in a sample. J. Appl. Ecol. 3:139-145.

Plessis, S.F. and J.H.E. Smith. 1973. Root distribution of mango. Citrus Subtropical Fruit J. 474:4-7.

Scholberg, J.M.S., L.R. Parsons, T.A. Wheaton, B.L. McNeal, and K.T. Morgan. 2002. Soil temperature, nitrogen concentration, and residence time affect nitrogen uptake efficiency of citrus. J. Environ. Qual. 31:759-768.

Sharma, D.D. and J.S. Chauham. 2005. Effect of different rootstocks on root distribution of Apple. Acta Hort. 696:167-171.

Thakur, R.S., M.S. Rajput, and K.C. Srivastava. 1981. Root distribution studies in some fruit crops with special reference to tracer technique-A review. Haryana J. Hort. Sci. 10:45-53.

Tinker, P.B. and P.H. Nye. 2000. Solution movement in the rhizosphere. Oxford University Press, N.Y.

Whitney, J.D., A. Elezaby, W.S. Castle, T.A. Wheaton, and R.C. Littell. 1991. Citrus tree spacing effects on soil water use, root density, and fruit yield. Trans. Amer. Soc. Agr. Eng. 34:129135. 